\title{
Effect of high dose aminosalicylic acid on gastroduodenal mucosa
}

\author{
DJ LEDDin, MD, DA MALATJALIAN, MD, D PALEy, DVM
}

DJ LEDDIN, DA MALATJALIAN, D PALEY. Effect of high dose aminosalicylic acid on gastroduodenal mucosa. Can J Gastroenterol 1993;7(3):319-321. Oral administration of a solution of aminosalicylic acid (5-ASA) $(60 \mathrm{~g} / 100 \mathrm{~mL})$ at a dosage of $80 \mathrm{mg} / \mathrm{kg} /$ day to dogs did not cause erosions or ulceration in the proximal gut. There was no biochemical or histological evidence of nephrotoxicity although high peak serum concentrations of the drug were obtained. High doses of 5-ASA may be used in the proximal intestine without gastroduodenal damage.

Key Words: 5-ASA, Dog, Duodenum, Stomach, Ulceration

\section{Effet d'une dose élevée d'acide aminosalicylique sur la}

\section{muqueuse gastroduodénale}

RÉSUMÉ: L'administration orale d'une solution d'acide aminosalicylique (5-AAS) $(60 \mathrm{~g} / 100 \mathrm{~mL})$ à une posologie de $80 \mathrm{~g} / \mathrm{kg} / \mathrm{j}$ à des chiens n'a pas causé d'érosions ni d'ulcérations au niveau de l'intestin proximal. Il n'y a pas eu de signe biochimique ni histologique de néphrotoxicité, bien que des concentrations sériques de pointe élevées du médicament aient été obtenues. Des doses élevées de 5-AAS peuvent être utilisées au niveau de l'intestin proximal sans atteinte gastroduodénale.

Departments of Medicine, Pathology and Animal Care, Victoria General Hospital, Dalhousie University, Halifax, Nova Scotia

Correspondence and reprints: Dr DJ Leddin, 4087 Dickson Centre, Victoria General

Hospital, Halifax, Nova Scotia B3H 2 Y9

Received for publication July 23, 1992. Accepted March 19, 1993 $\triangle$ Minosalicylic ACID (5-ASA) IS Istructurally similar to acetylsalicylic acid, a drug which injures the gastroduodenal mucosa (1). The purpose of this study was to investigate whether oral administration of a suspension of 5-ASA ( $4 \mathrm{~g} / 60 \mathrm{~mL})$ also causes gastroduodenal injury, and to determine if this formulation affects renal and hematological function. The kinetics of absorption were also studied.

\section{METHODS}

Twelve conditioned (six control and six experimental) parasite-free, female ex-breeder, Beagle dogs were studied. Baseline hematological, bone marrow, biochemistry and urine parameters were obtained in all animals. Urinary specific gravity, osmolality, protein and $\mathrm{pH}$ were measured after an overnight fast. The urine was examined microscopically for the presence of casts. Blood and urine studies were performed twice 
TABLE 1

Results of the urinary parameters

\begin{tabular}{|c|c|c|c|c|}
\hline & \multicolumn{2}{|c|}{ Pre-treatment } & \multicolumn{2}{|c|}{ End of study } \\
\hline & Control & $\begin{array}{c}\text { Aminosalicylic } \\
\text { acid }\end{array}$ & Control & $\begin{array}{c}\text { Aminosalicylic } \\
\text { acid }\end{array}$ \\
\hline Urea (mmol/L) & $4.7 \pm 0.3$ & $5.5 \pm 0.5$ & $5.1 \pm 0.7$ & $6.6 \pm 1.0$ \\
\hline Creatinine $(\mu \mathrm{mol} / \mathrm{L})$ & $64.2 \pm 3.1$ & $70.2 \pm 3.2$ & $65.8 \pm 2.1$ & $75.2+4.9$ \\
\hline Osmolality (mosmol/kg) & $1562 \pm 349$ & $1861 \pm 200$ & $1579 \pm 246$ & $1593 \pm 339$ \\
\hline Specific gravity & $1.027 \pm 0.00$ & $1.032 \pm 0.00$ & $1.037 \pm 0.01$ & $1.034 \pm 0.00$ \\
\hline Protein $(\mathrm{g} / \mathrm{L})$ & $0.15 \pm 0.05$ & $0.22 \pm 0.16$ & $0.19 \pm 0.07$ & $0.42 \pm 0.12$ \\
\hline $\mathrm{pH}$ & $6.4 \pm 0.4$ & $6.33 \pm 0.56$ & $6.4 \pm 0.51$ & $6.4 \pm 0.25$ \\
\hline
\end{tabular}

The mean \pm standard error of the mean urea, creatinine, urine osmolality, urinary specific gravity, urinary protein and urinary $\mathrm{pH}$ pretreatment and at the end of the study

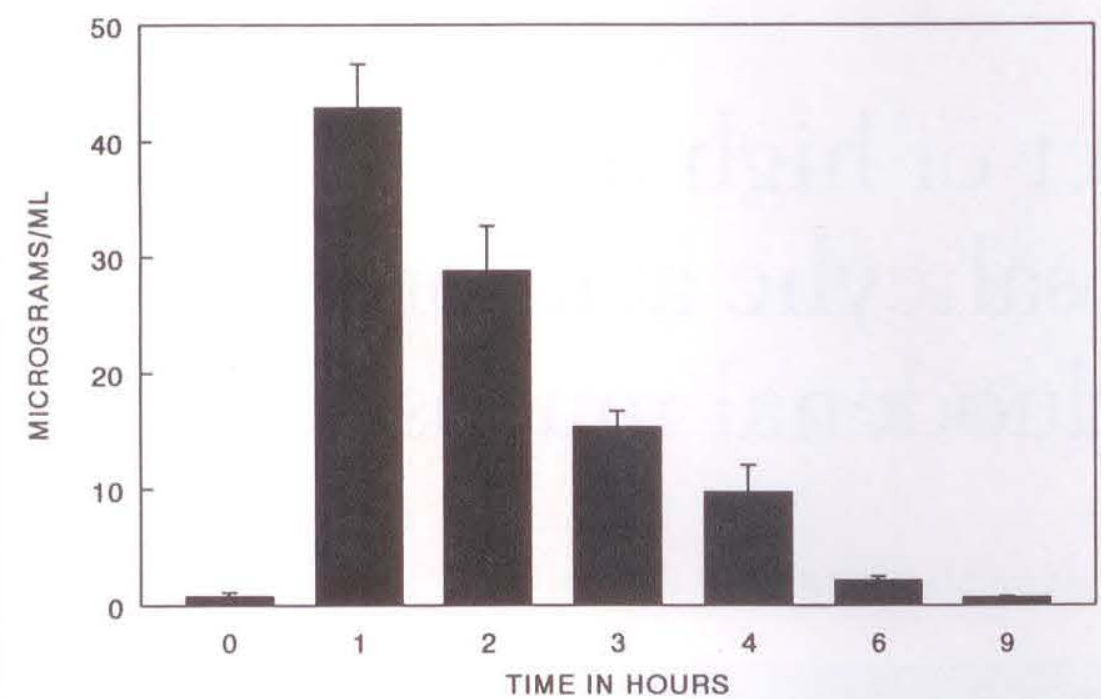

Figure 1) Aminosalicylic acid (5-ASA) levels in $\mu \mathrm{g} / \mathrm{mL}$ of serum (mean \pm standard error of the mean) pre and post administration of 5-ASA

weekly during the study and marrow aspirate repeated at the study's end.

5-ASA was administered orally, twice daily for 15 days, by syringe at a dose of $40 \mathrm{mg} / \mathrm{kg}$. Controls received the same volume of saline but no active drug. After eight days, blood for 5-ASA levels was taken prior to the morning dose and at 1, 2, 3, 4, 6 and $9 \mathrm{~h}$ post dose. The serum was separated, frozen at $20^{\circ} \mathrm{C}$ and shipped on dry ice for analysis of 5-ASA and N-acetyl 5-ASA levels.

At termination of the study all animals underwent a complete autopsy by an experienced pathologist following sacrifice with barbiturate. The pathologist was unaware of whether the animal was a control or 5-ASAtreated. Gross abnormalities were recorded. Samples were taken of bone marrow as well as all internal organs for light microscopy. Microscopic abnormalities were scored as: 1 , mild; 2 , moderate; 3 , severe.

Statistical analysis: The hematological, biochemical and renal parameters were analyzed by Profile Analysis using SAS. The nonparametric data were analyzed by MannWhitney testing.

Missing data were analyzed in two ways. First, any animal with a missing value was deleted from the analysis. Second, the missing data were estimated by BMDP SV statistical estimation.

\section{RESULTS}

Clinical status: No adverse effects were observed in any of the control or 5-ASA animals. They ate normally and diarrhea did not occur.

Renal function: The results of the urinary parameters are shown in Table 1 . There was no difference between the groups at randomization or during treatment, with the exception of urinary specific gravity which was higher in the control group $(P=0.0004)$ when analyzed by BMDP but not by deletion $(\mathrm{P}=0.07) .5$-ASA did not increase the number of urinary casts. No epithelial or granular casts were seen.

Hematological function: There was no difference between the groups when analysed for a drug effect on white blood cell count, hemoglobin, platelet count or bone marrow morphology.

Histology: No abnormalities were detected in the esophagus of either control or 5-ASA-treated animals. The proximal stomach, antrum and duodenum were normal grossly. There was no significant difference between control and 5-ASA treated animals when tissue was examined for erosions, ulceration, mononuclear and polymorphonuclear infiltration, glandular hyperplasia or edema.

In the small intestine no gross lesions were observed. There was no significant difference in the villus height, width or crypt depth between the two groups. The number of blebs in the 5-ASA group approached a significant difference from the controls $(\mathrm{P}<0.06)$ but there was no difference in the number of ruptured blebs or in the total percentage of blebs and ruptured blebs.

No gross abnormalities were seen in the kidneys. On microscopy, hydropic change was seen in some animals in both groups. The sum score was not different ( 3.0 versus 1.0 [not significant]) by Mann-Whitney analysis.

Kinetics of absorption: The results are shown in Figure 1. Detectable 5-ASA was present in the serum prior to administration of the morning dose although the level was low $(0.75 \pm 0.35$ $\mu \mathrm{g} / \mathrm{mL}$ ). Absorption peaked in the first hour after administration (maximum level $42.9 \pm 3.8 \mu \mathrm{g} / \mathrm{mL}$ ) and declined 
with time. The levels at $9 \mathrm{~h}(0.65 \pm 0.13$ $\mu \mathrm{g} / \mathrm{mL}$ ) were not significantly different from those at $12 \mathrm{~h}$.

Virtually no acetyl 5-ASA was detectable in the serum. At $\mathrm{O}$ h the level was $0.07 \pm 0.03 \mu \mathrm{g} / \mathrm{mL}$ and this peaked 1 $\mathrm{h}$ after the 5-ASA peak at $0.16 \pm 0.03$ $\mu \mathrm{g} / \mathrm{mL}$.

\section{DISCUSSION}

Crohn's disease may involve the proximal intestine (2). At present there is no formulation of 5-ASA designed to deliver high concentrations of the drug to this area. Intraduodenal infusion of a suspension of 5-ASA $(4 \mathrm{~g} / 250 \mathrm{~mL})$ has been used in patients with proximal gut involvement and the results have been sufficiently encouraging to warrant a controlled clinical trial (3).

5-ASA inhibits the cyclo-oxygenase pathway of arachidonic acid metabolism (4). Inhibition of this pathway by nonsteroidal anti-inflammatory drugs (NSAIDs) is associated with the development of gastroduodenal ulceration (5). The results of this study indicate that 5-ASA, in contrast to NSAIDs, does not cause gross or microscopic damage to the canine stomach and duodenum, even when given in high doses.

Inhibition of prostaglandin synthesis is also associated with renal impairment
(6), and 5-ASA has been reported to cause nephrotoxicity (7). Early nephrotoxicity may be manifested by a decrease in urinary concentrating ability. The urinary specific gravity was higher post treatment in the control group but no difference was seen in urinary osmolality, a more sensitive estimate of urinary concentrating ability. No other adverse effects on renal function were detected either biochemically or on microscopy despite high peak serum concentrations of the drug.

5-ASA has also been associated with thrombocytopenia (8). In this study no adverse effects were seen on peripheral blood counts or on bone marrow histology.

The suspension of 5-ASA was rapidly absorbed with peak concentrations at $60 \mathrm{mins}$. The dog is phytogenetically distinct and, unlike the human, does not acetylate organic compounds (9). Therefore virtually no N-acetyl 5-ASA was detected in the serum of the animals.

\section{CONCLUSIONS}

5-ASA, at a dosage of $80 \mathrm{mg} / \mathrm{kg} /$ day in a nonenteric coated formulation, does not cause esophageal, gastric or duodenal inflammation in the dog; this supports the contention that high doses of this drug may be used without fear of gastroduodenal damage.

\section{REFERENCES}

1. Roth S, Agrawal N, Mahowald M, et al. Misoprostil heals gastroduodenal injury in patients with rheaumatoid arthritis receiving aspirin. Arch Intern Med 1989;149:775-9

2. Danzi J, Farmer RG, Sullivan BH, Rankin GB. Endoscopic features of gastroduodenal Crohn's disease. Gastroenterology 1976;70:9

3. Williams $\mathrm{CN}$, Morgan E. Pharmacokinetics of 5-aminosalicylic acid enteral suspension in Crohn's disease patients and normal volunteers. Can J Gastroenterol 1990;4:458-62.

4. Sharon P, Ligumsky M, Rachmilewitz D, Zor U. Role of prostaglandins in ulcerative colitis. Enhanced production during active disease and inhibition by sulfasalazine. Gastroenterology 1978;75:638-40.

5. Soll AH, Kurata J, McGuigan JE. Ulcers, non-steroidal antiinflammatory drugs, and related matters. Gastroenterology 1989;96:561-8.

6. Toto RD. The role of prostaglandins in NSAID induced renal dysfunction. J Rheumatol 1991;18(Suppl 28):22-5.

7. Calder IC, Funder CC, Green CR, Ham KN, Tange JD. Nephrotoxic lesions from 5-aminosalicylic acid. Br Med J 1972; Jan:152-4.

8. Daneshmend TK. Mesalazineassociated thrombocytopenia. Lancet 1991;337:1297-8.

9. Papich MG, Davis LE, Davis CA, McKiernan BC, Brown SA.

Pharmacokinetics of procaineamide hydrochloride in dogs. Am J Vet Res 1986;47:2351-8. 


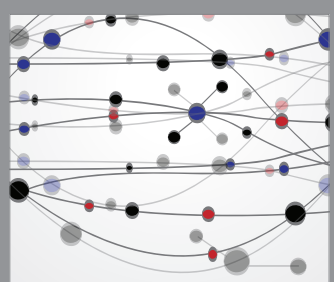

The Scientific World Journal
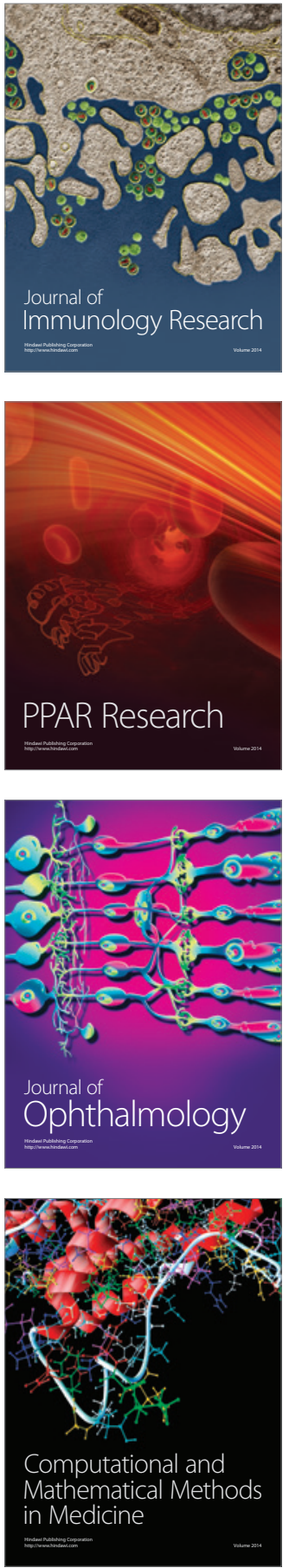

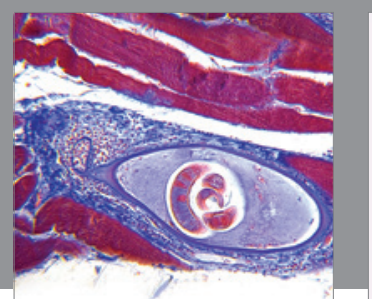

Gastroenterology Research and Practice

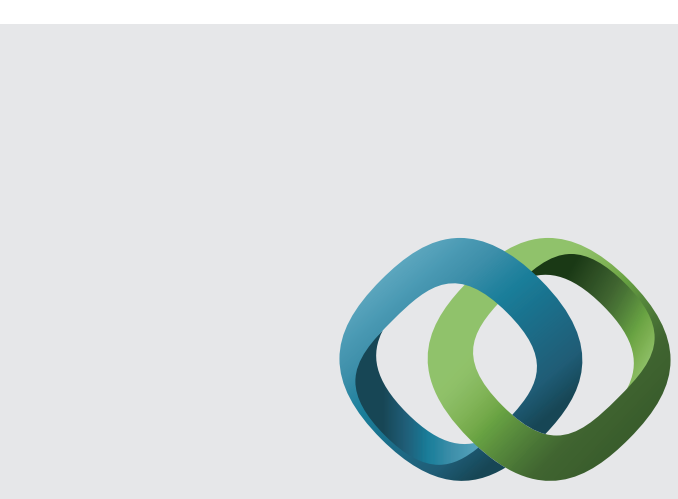

\section{Hindawi}

Submit your manuscripts at

http://www.hindawi.com
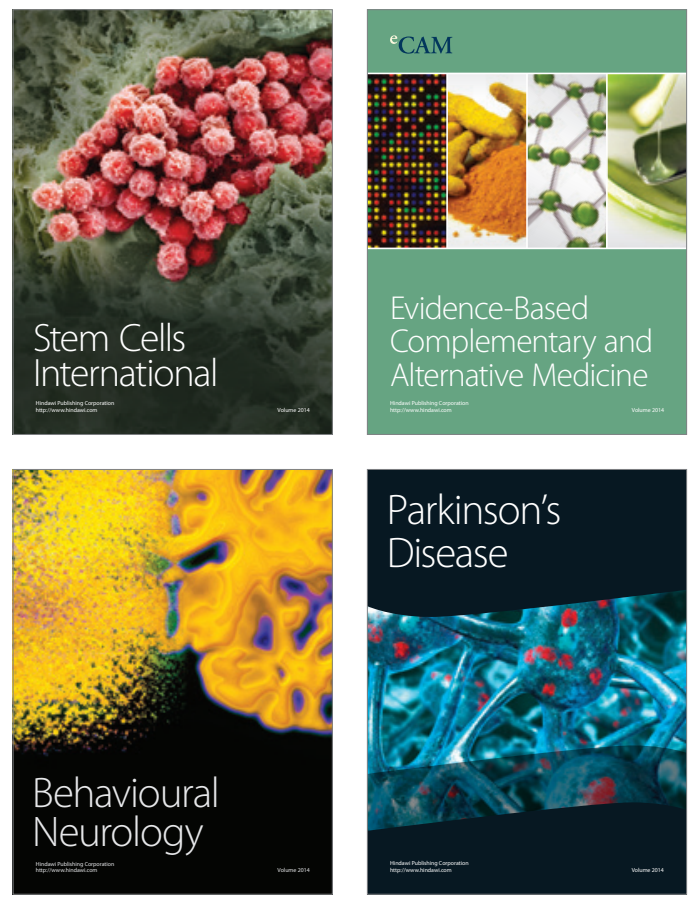
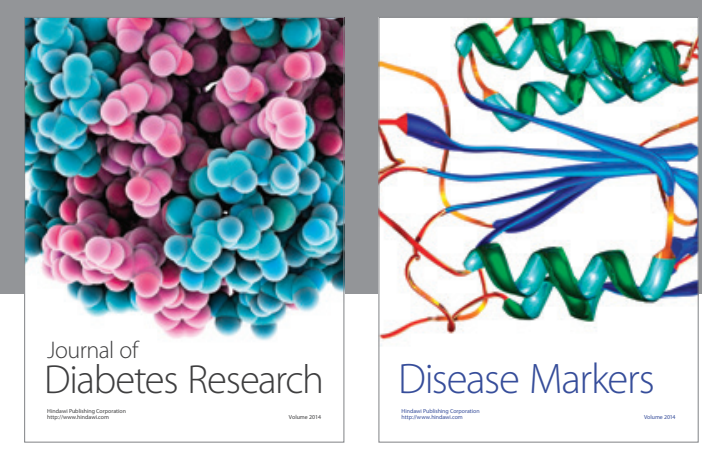

Disease Markers
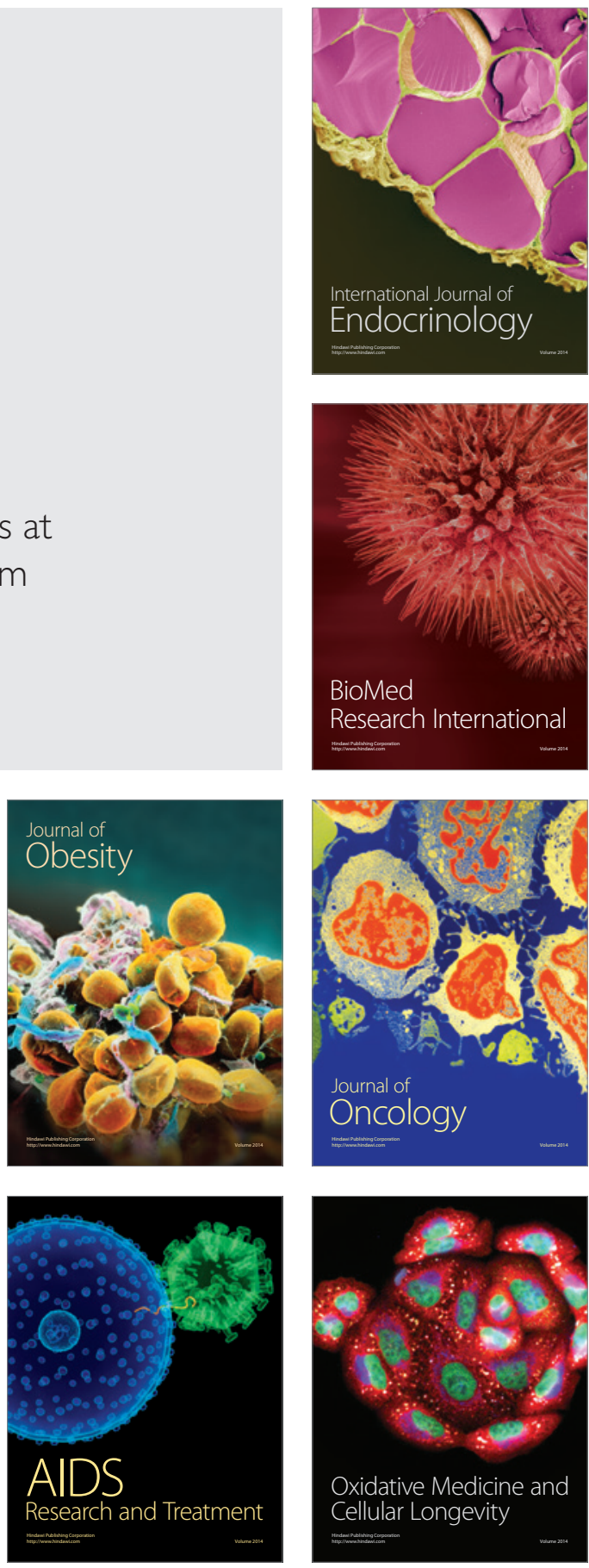